\title{
Convergent Tectonics and Coastal Upwelling: A History of the Peru Continental Margin
}

\author{
by Roland von Huene, Erwin Suess and Kay-Christian Emeis
}

(on behalf of the Leg 112 Shipboard Scientific Party)

The geological evolution of the western margin of South America has long been a challenge to geologists interested in convergent plate tectonics. Late in 1986, scientists on the ODP drillship JOIDES Resolution confirmed that the upper slope of the Peruvian margin consists of continental crust whereas the lower slope comprises an accretionary complex. An intricate history of horizontal and vertical movements can be detected, and the locations of ancient centers of upwelling appear to have varied, partly due to tectonic movements of the margin. In this review of Leg 112 , the three scientific leaders on this cruise discuss their results. (Ed.)

\section{Introduction}

During Leg 112 of the Ocean Drilling Program, which took place during November and December 1986, the RV JOIDES Resolution investigated ten sites on the Peruvian margin (Fig. 1). Drilling provided sediment samples of Eocene age deposited when the sedimentary record of the present margin began, of Miocene age laid down during a major phase of Andean uplift, and of Pliocene and Quaternary age recording the period when the modern coastal upwelling system became well established. The uplift of the Peruvian Andes is linked with the convergence of the South American and Pacific plates. As the Andes were built, the changing shape of the land was accompanied by morphological changes of similar magnitude beneath the sea. Convergent margin processes, whereby thousands of kilometres of oceanic crust were subducted, have resulted in a great change in the morphology of the continental margin since Eocene time.

Because convergent margins are generally considered accretionary, a gradual uplift of the front of the margin should take place as successive thrust slices are added to the continent. Off Peru, however, evidence had been gathered from geophysical data and dredge samples that indicated the upper continental slope was affected by extensional faulting during subsidence (Hussong and Wipperman, 1981; Thornburg and Kulm, 1981; Hussong and Taylor, 1985; Reed and Hussong, 1985; von Huene et al., 1985; Thornburg, 1985; Bourgois et al., 1986). Consequently, it appeared the coastal zone had migrated landward through time, an inference that could be verified by drilling deeper than could be sampled with conventional oceanographic techniques, and by studying the paleo-depth indicated by the bio- and lithostratigraphy of sediments filling the forearc basins.
Such sediment includes the distinctive organic-rich coastal upwelling facies, a facies important to exploration for hydrocarbon resources (Suess et al., 1987; Suess and Thiede. 1983; Thiede and Suess, 1983). The centers of upwelling generate oxygen-deficient upper-slope waters that enhanes the preservation of organic matter. The latter, in conjuction with biogenic skeletal components, records a detailed history of past oceanographic conditions. The oxygenminimum zone impinges onto the seafloor within a restricted depth range, and thus its sediment record is also dependent on basin subsidence.

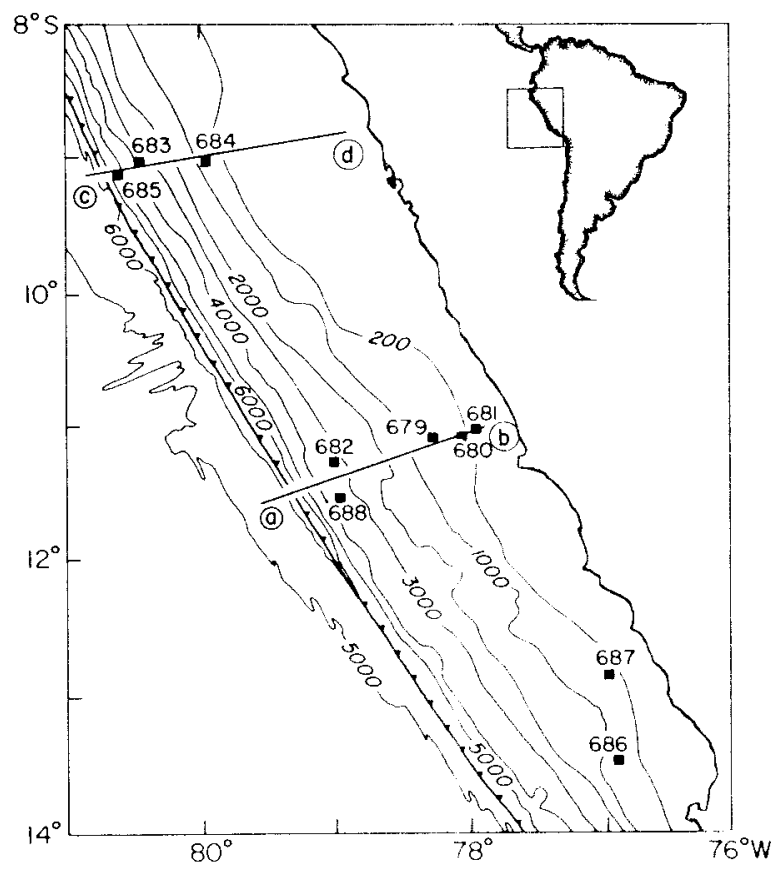

Figure 1: The bathymetry of the Peru continental margin, showing the sites drilled during ODP Leg $112 ; a-b$ and $c-d$ are transects shown in Figures 2 and 3. Sites 679, 682 are on the eastern and western flanks of the Lima Basin, 684 the Trujillo Basin, 680 and 681 the Salaverry Basin, and 686 and 687 the West Pisco Basin. 


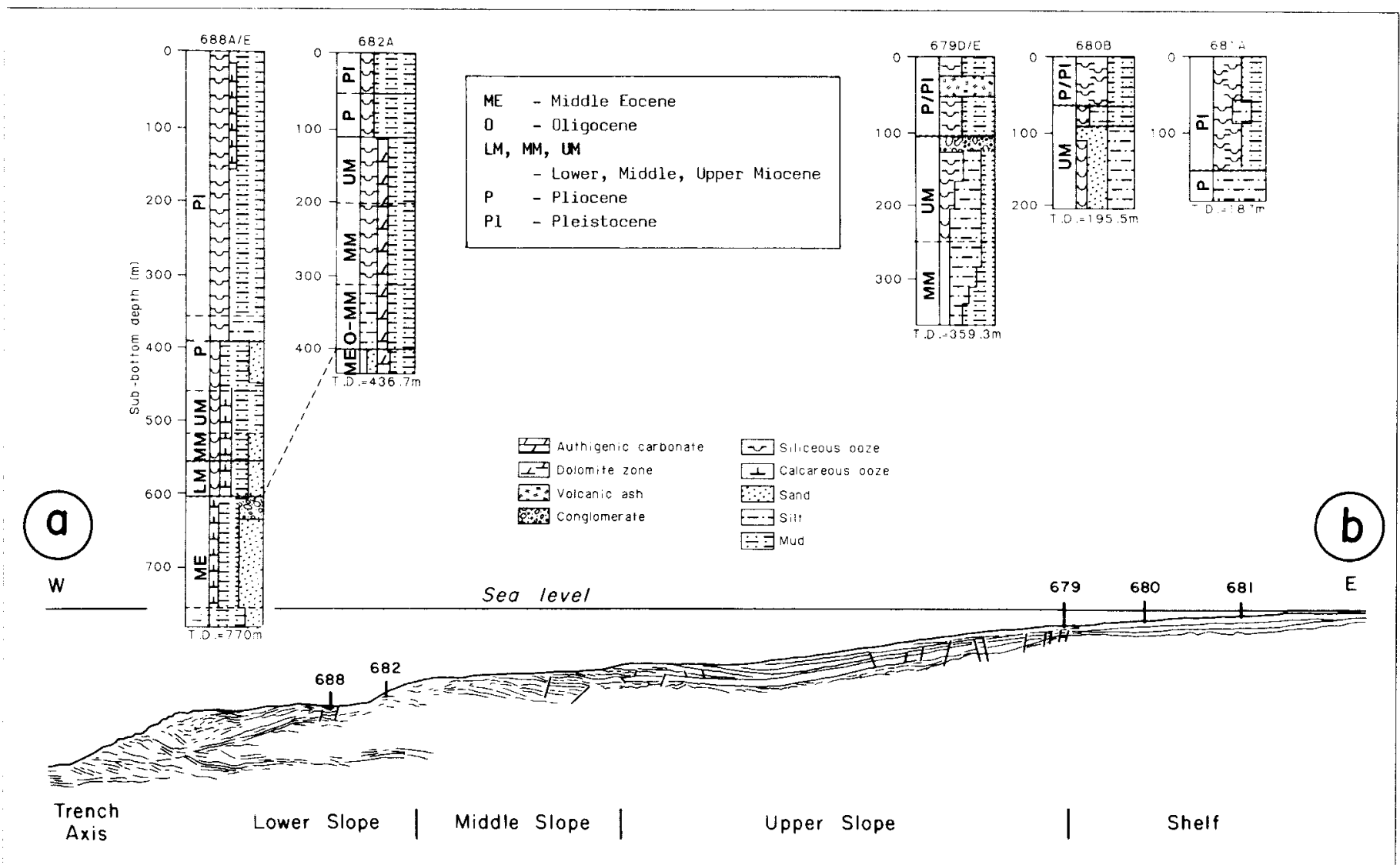

Figure 2: Seismic section and drill hole results along the southern transect of the peru margin at $11^{\circ} \mathrm{S}$ latitude. Width of columns is in proportion to the estimated percentage. Vertical axis of seismic record is in time (after von Huene and Miller, in preparation).

This was the background to Leg 112 , during which two major topics were addressed: the tectonic history of the margin and the paleoenvironmental history. The tectonic evolution of the Peruvian margin and foreare basins and its temporal relation to Eocene and younger plate tectonic history was investigated along two E-W transects at $9^{\circ}$ and $11^{\circ} \mathrm{S}$ latitude (Fig. 1). The paleoenvironmental record of coastal upwelling deposits in four morphological settings, and the time of onset, and nature of upwelling along the Peruvian coast were studied along a $\mathrm{N}-\mathrm{S}$ profile of shallow-water sites on the shelf.

\section{Tectonic History}

The Eocene section was sampled at three sites on the middle and lower slope of the continental margin. The longest section, at Site 688 on the seaward end of the southern transect (Fig. 2), yielded shelf assemblages of benthic foraminifera, rare articulated megafossils, conglomerate, sandstone, current laminated siltstone, and limestone. The lower part of the Middle and Lower Eocene section contained mudstones deposited in an upper slope environment. The sediment sequence is like that onshore, including three formations found in coastal areas. This sequence is cut by a regional Oligocene unconformity. At Site 682 , a short distance up the lower slope from 688, the top of this Eocene sequence was sampled again below the Oligocene unconformity. The correlative reflections in seismic records extend to a point $15 \mathrm{~km}$ landward of the trench axis and reach a depth of about $6.2 \mathrm{~km}$ below sea level. Thus the onshore Eocene section, deposited in shelf and upper-slope environments, was traced about $160 \mathrm{~km}$ seaward.

Above the Oligocene unconformity are Miocene mudstones deposited in a continental slope environment. These mudstones contain abundant transported microfossils and in situ benthic foraminiferal assemblages from the lower to middle bathyal depth zones $(500 \mathrm{~m}$ to $4000 \mathrm{~m})$. The increased rates of Widdle and Late Miocene sedimentation at Site 682, together with the abundance of reworked components, reflect erosion now recorded by an unconformity beneath Lima Basin some 20 to $30 \mathrm{~km}$ up-slope (Fig. 2). This section contains soft-sediment deformational structures that are commonly attributed to gravity sliding on the slope.

Site 679 is just beyond the edge of the shelf in $461 \mathrm{~m}$ of water (Fig. 2). The upper muds, characterized by transported products from the latest Miocene and Quaternary coastal upwelling, end at $245 \mathrm{~m}$ at a $4 \mathrm{Ma}$ regional hiatus. Below are Middle Miocene mudstones, siltstones and turbidites. The hiatus is marked by high-amplitude reflections in seismic records and in the synthetic seismograms derived from the drill logs. The high-amplitude reflections form a distinctive horizon that can be followed from Site 679 to beneath the Lima Basin where the hiatus becomes the regional angular unconformity that floors the basin. Local erosion along the unconformity has removed up to $\mathrm{l} \mathrm{km}$ of tilted beds indicating vigorous wave-base erosion. A probable wave-base erosional origin is consistent with results from the study of dredged samples.

The $500 \mathrm{~m} / \mathrm{Ma}$ subsidence rate of the Lima Basin is based on studies of benthic foraminifera (Kulm et al., 1981; Kulm, Suess et al., 1984) and is similar to the $450 \mathrm{~m} / \mathrm{Ma}$ rate obtained by assuming that the 8 Ma-old unconformity subsided from sea level to its present $3450 \mathrm{~m}$ depth. This interpretation is also consistent with the recovery at the 


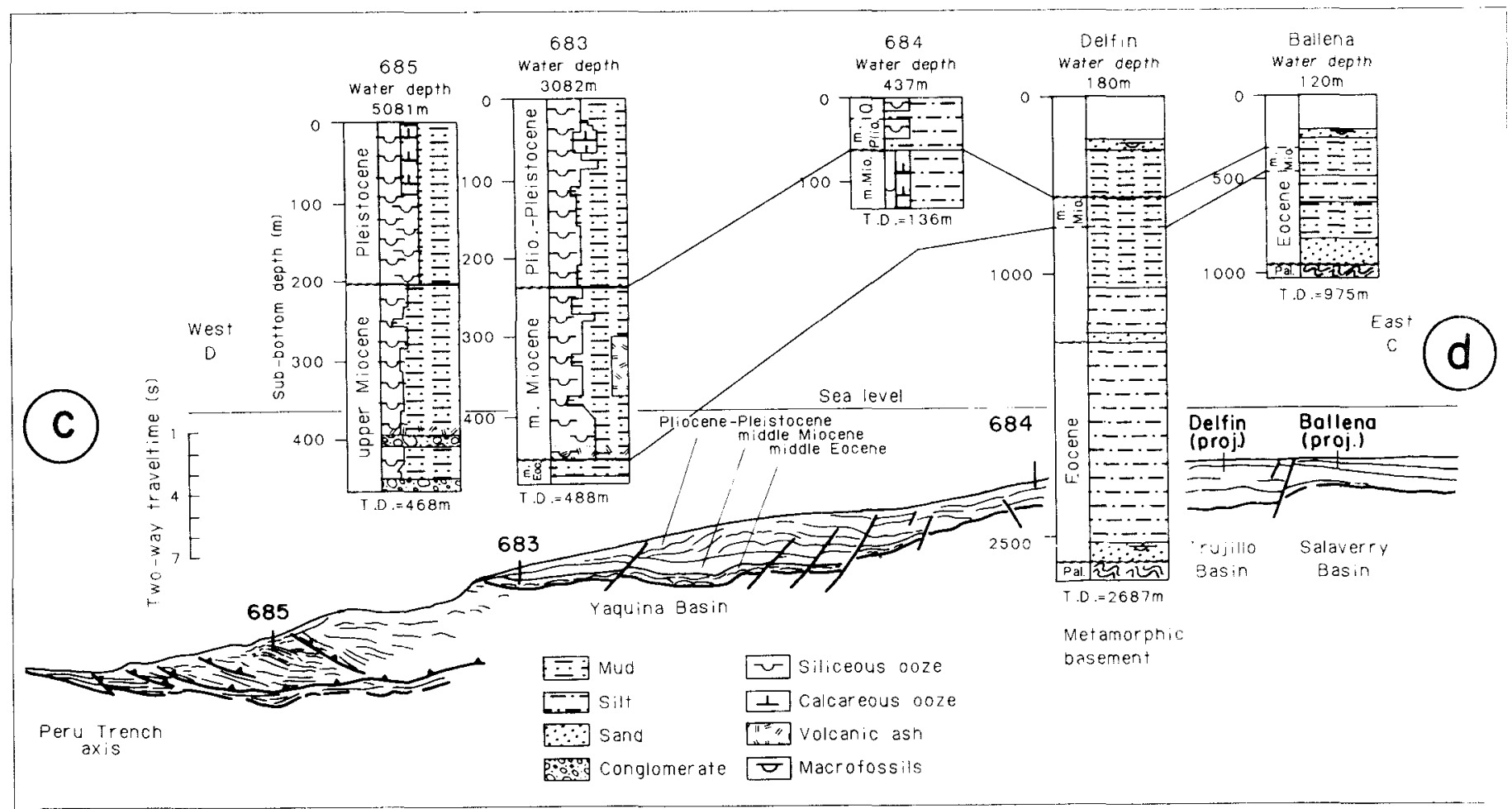

sites seaward of the Lima Basin of a laminated, nonreworked sediment of the coastal upwelling facies of Late Miocene age. This facies is presently restricted to depths ranging from $100 \mathrm{~m}$ to $300 \mathrm{~m}$ at the latitude of the transect, thus indicating a shallow-water environment seaward of the Lima Basin 5 Ma ago. We postulate, therefore, that the Middle Miocene slope deposits were uplifted, eroded at wave-base in Middle and Late Miocene time, subsided rapidly after $5 \mathrm{Ma}$, and covered by sediment transported from the shelf that fills the Lima Basin.

The northern transect $\left(9^{\circ} \mathrm{S}\right)$ is representative of another segment of the Peru margin where the shelf is about $120 \mathrm{~km}$ wider and where the Lima Basin counterpart, the Trujillo Basin, is at much shallower water depths (Fig. 3). This basin did not share the history of uplift and subsidence observed in the Lima Basin, as indicated by probable Upper Miocene and younger sands with megafossils near the top of two industry wells (Kulm, Thornburg et al., 1984).

At Site 683 , near the foot of the upper slope in $3082 \mathrm{~m}$ of water, a thin time-equivalent of the Trujillo and Yaquina Basin section was sampled. The cores yielded a tie to the seismic stratigraphy in Yaquina Basin. The Middle Miocene, a mudstone, is sandwiched between two hiatuses. The lower one of Oligocene age lasted about $25 \mathrm{Ma}$ and separates Middle Miocene rock from indurated sandy mudstones of Middle Eocene age. The Eocene contains shallow water nanno-fossils and upper to upper/middle bathyal benthic foraminifera, although the latter could be transported forms. Seismic records indicate an unconformity on crystalline basement $250 \mathrm{~m}$ below the top of the Eocene unit, as was found in the industry wells. The section indicates that during Eocene time the site was on crystalline continental crust that later subsided, and not on an uplifted oceanic element accreted to the front of the margin.

At Site 685 , almost $20 \mathrm{~km}$ down-slope from Site 683 and on a thrust packet with landward dipping reflections, the sediment accreted at the front of the Peru margin was cored. Because of its proximity to the outer part of the boundary between continental crust and accreted complex, some of the oldest sediment in the latter was sampled. There is a clear lithologic and structural division between
Figure 3: Summary of the northern transect of the Peru margin at $9^{\circ} \mathrm{S}$ latitude. Vertical axis of seismic record is in time (after von Huene et al., 1985).

slope sediment and accreted sediment. The 200-m thick Pleistocene slope sequence consisted mainly of diatomaceous muds with abundant microfossils transported from the shelf. The lower $120 \mathrm{~m}$ of the slope sequence displays minor folding, a variably developed fissility, and a planar fabric cutting bedding at high angles.

A hiatus of at least $4.3 \mathrm{Ma}$ separates the slope sediment from the underlying accreted sediment of Late Miocene age $(6.1$ to $6.8 \mathrm{Ma})$. These are diatom-bearing mudstones, calcareous mudstones, vitric tuffs, and sedimentary breccias with clasts of Eocene and younger slope sediments. The clasts suggest massive failure up-slope. A strong, beddingparallel, scaly fabric is developed throughout, and compressional fracturing occurs in the lower part. The lithologies and structures are consistent with the proposed accretionary origin of these sediments, and the Late Miocene age indicates the time when accretion prevailed over other tectonic processes along the trench.

The tectonic history of the $9^{\circ} \mathrm{S}$ transect also indicates subsidence of the Eocene shelf and upper slope that extended at least to the modern mid-slope area. The seaward part of the shelf became submerged, as did topographic lows in the Trujillo Basin along the shelf of north-central Peru. The time of most rapid subsidence along the $9^{\circ} \mathrm{S}$ transect is associated with the regional hiatus of Oligocene age because the foot of the modern upper slope was already at lower bathyal depth zone by Middle Miocene time.

The subsidence along the Peru margin since Oligocene time indicates a dominantly non-accretionary convergent margin prior to $5 \mathrm{Ma}$ ago. Superimposed on this basic subsidence is a vertical tectonic history unique to each segment of the margin. The difference in uplift and subsidence histories of the Lima and Trujillo Basins is difficult to attribute to a difference in plate interaction since both segments of the 
type of tectonic control where slow subsidence was continuous over a long period of time while the basin shelf slope and shore configuration and, hence, the oceanographic conditions remained unchanged.

$\begin{array}{llll}\text { Lithology and sedimentary } & \text { Depth } & \text { Relative } & \text { Ages of Cycle Boundaries } \\ \text { structures } & \text { below sea } & \text { sea level }{ }^{2} & \text { Site } 686^{4} \\ & \text { floor }(\mathrm{m}) & & \text { Eustatic }^{1}\end{array}$

Unit 0: Not recovered 3

high

Unit 1: Laminated diatomaceous mud with sand and silt layers

low

$27 \pm 2$

0.15

Unit 2: Burrowed diatomaceous mud with beds of sand and silt

Unit 3: Laminated diatomaceous mud

high

$98 \pm 3$

$0.51 \pm 0.02$

0.50

low

$150 \pm 5$

$0.79 \pm 0.01$

0.80

Unit 4: Burrowed diatomaceous mud with layers of shelly beds

$1.19 \pm 0.03$

Unit 5: Laminated diatomaceous mud

Unit 6: Burrowed diatomuceous mud with layers of shelly beds

low

$1.38 \pm 0.03$

$1.6^{5}$

high

1 Ages of cycle boundaries in million years are based on Haq et al., 1987 and Imbrie et al., 1984. ${ }^{2}$ Low stands of sea level coincide with periods during which laminated sediments formed and high organic carbon and biogenic silica were deposited.

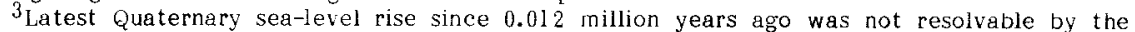
shipboard sampling.

4 Ages of cycle boundaries based on age estimates (assuming constant sedimentation rate) in Holes $686 \mathrm{~A}$ and $686 \mathrm{~B}$.

${ }^{5}$ Discrepancy in estimate of cycle boundary age is probably due to slower rates of sedimentation prior to 1.2 million years than the constant rate of $190 \mathrm{~m} / \mathrm{ha}$ as assumed for the entire Quaternary Period.

Peru margin have experienced roughly the same plate convergence history. The beginning of the modern accretionary complex in the northern transect does correspond in time to subduction of the Nazca Ridge, an increase in rate of plate convergence, and the general increase in sedimentation during the Miocene. Any Neogene material accreted prior to subduction of the ridge would have been eroded.

\section{Paleoenvironment}

The record of paleoenvironmental conditions is closely linked to the tectonic history of the slope and shelf basins. During Leg 112, parts of four such basins with different tectonic histories were drilled. Sites 679 and 682 were located along the easternmost flank and western edge of the Lima Basin, which had a rapid subsidence history during Neogene time and which preserved a long-time record of upwelling. The Trujillo Basin (Site 684) remained just below Quaternary sea-level fluctuations and thus collected a condensed sediment record. The Salaverry Basin (depositional center, Sites 680,681 ) was affected by changing configuration of the coastline and uplift of the subaerial barrier during Late Miocene time. The Pliocene/Quaternary history is well preserved here, particularly since the beginning of the Pleistocene. Sites 686 and 687 are along the stable northern flank of the West Pisco Basin, which experienced a
The Quaternary sequences in the Salaverry Basin and the West Piseo Basin (Fig. l) contain laminations on a millimetre and sub-millimetre scale. Other properties, such as water content, porosity, and organic carbon contents, revealed alternations on the scale of metres; interbeds of laminated and bioturbated units alternate at lower frequencies on the order of several tens of metres. This observed cyclicity is climatically forced and contains a superb record of past coastal upwelling.

As a first approximation, we identified three major cycles with boundary ages $0.14,0.8$, and $1.4 \mathrm{Ma}$ old (Table 1) each comprising a set of laminated and bioturbated units. Their ages, based on simplified linear interpolation for the Quaternary, coincide with the observed cycles of Cenozoic eustatic sea-level fluctuations (Haq et al., 1987) and with cycles based on the orbital theory (Imbrie et ai., 1984). Superimposed on these first-order, long-term cycles are higher frequency alternations between water-rich laminated diatomaceous muds and burrowed sandy/silty muds with low water contents.

Using an average cycle thickness of 20 metres and the same linearly extrapolated sedimentation rate, an average cycle duration of 105,000 years is obtained. This cycle duration is close to the long-term variation in the Earth's orbital 


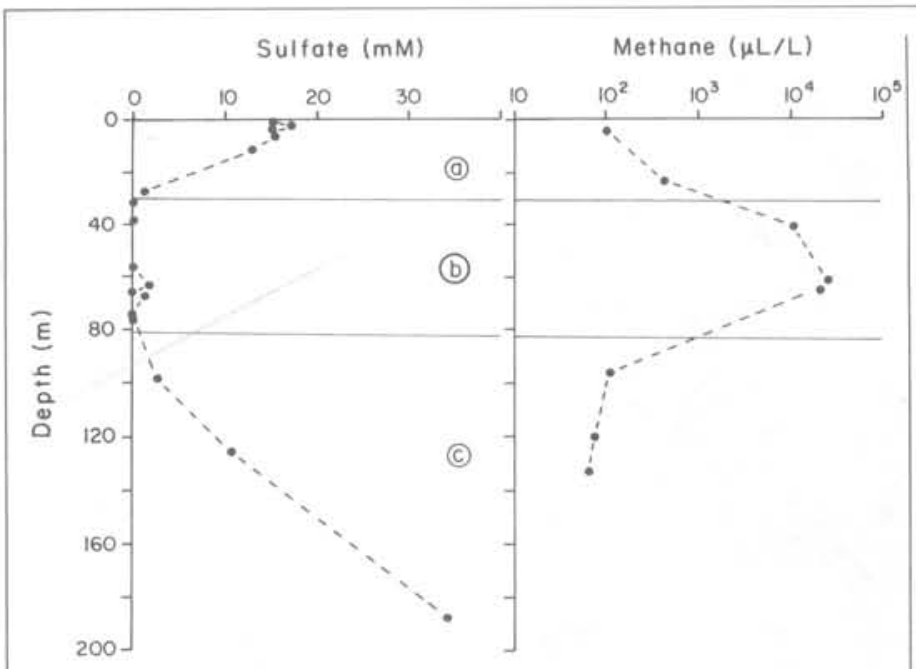

Figure 4: Dissolved sulphate and methane distribution at Site 681; Zone (a) is characterized by sulphate reduction, zone (b) by methanogenesis, and zone (c) again by sulphate reduction due to replenishment of sulphate from an underlying brine. Vertical axis shows depth below sea floor.

eccentricity and corresponds to the cycle length that has been widely recognized in deep-sea sediments; it is attributed to climatically induced variations in primary productivity and/or preservation of biogenic constituents (Pisias et al., 1984; Imbrie et al., 1984; Martinson et al., 1987).

Additional evidence for the nature of climatically induced variability in the sediments comes from investigation of diatom assemblages. The diatom record indicates alternating influence of warm and cold water for the entire Pleistocene Epoch. The West Pisco Basin sites, positioned underneath present-day upwelling centers, contain flora that indicate repeated episodes of strong coastal upwelling, changes in water temperature, and high productivity. These diatom assemblages are excellently preserved in laminated units that were deposited during glacial low sea-level stands of the Pleistocene. Highest primary productivity during glacial periods was also observed for the upwelling regime off northwest Africa. Assemblages indicative of prolonged times with no coastal upwelling, warmer oceanic temperatures, and normal continental margin productivity coincide with high sea-level stands and more bioturbated units, as also observed by Schuette and Schrader (1979).

Recognition and evaluation of high-resolution climatic and oceanographic signals of the type presented here were the most important paleoceanographic objectives of drilling on the Peru margin and will form the basis for future studies of ancient coastal upwelling. The preliminary conclusions presented here are based solely on shipboard observations, and our data hold great potential for the reconstruction of a detailed history of the Peru upwelling regime.

\section{Subsurface Brine}

The most surprising find of Leg 112 was the discovery of fluids in sediments that were twice as salty as normal seawater. The maximum chloride content measured was 1043 $\mathrm{mmol} / \mathrm{l}$. The chloride gradients appear to be diffusion profiles between this highly concentrated solution and seawater. The strata containing the brine source was not reached in any of the holes, although the steepness of the gradients indicates that at Site 684 we were closest to it. Chloride is a conservative tracer because it does not participate in any mineral dissolution or precipitate reactions, and it can be used best to delineate the regional and depth distribution of the brine over the Peru upper shelf and slope.

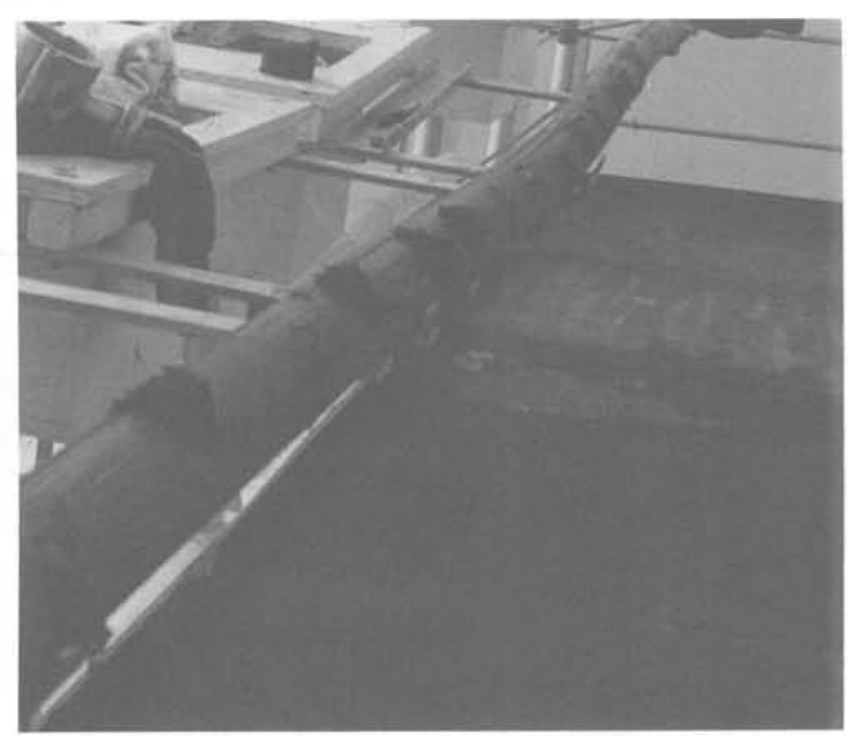

Figure 5: Sediment extruding from holes punched in core to release methane. Photo by P. Hill.
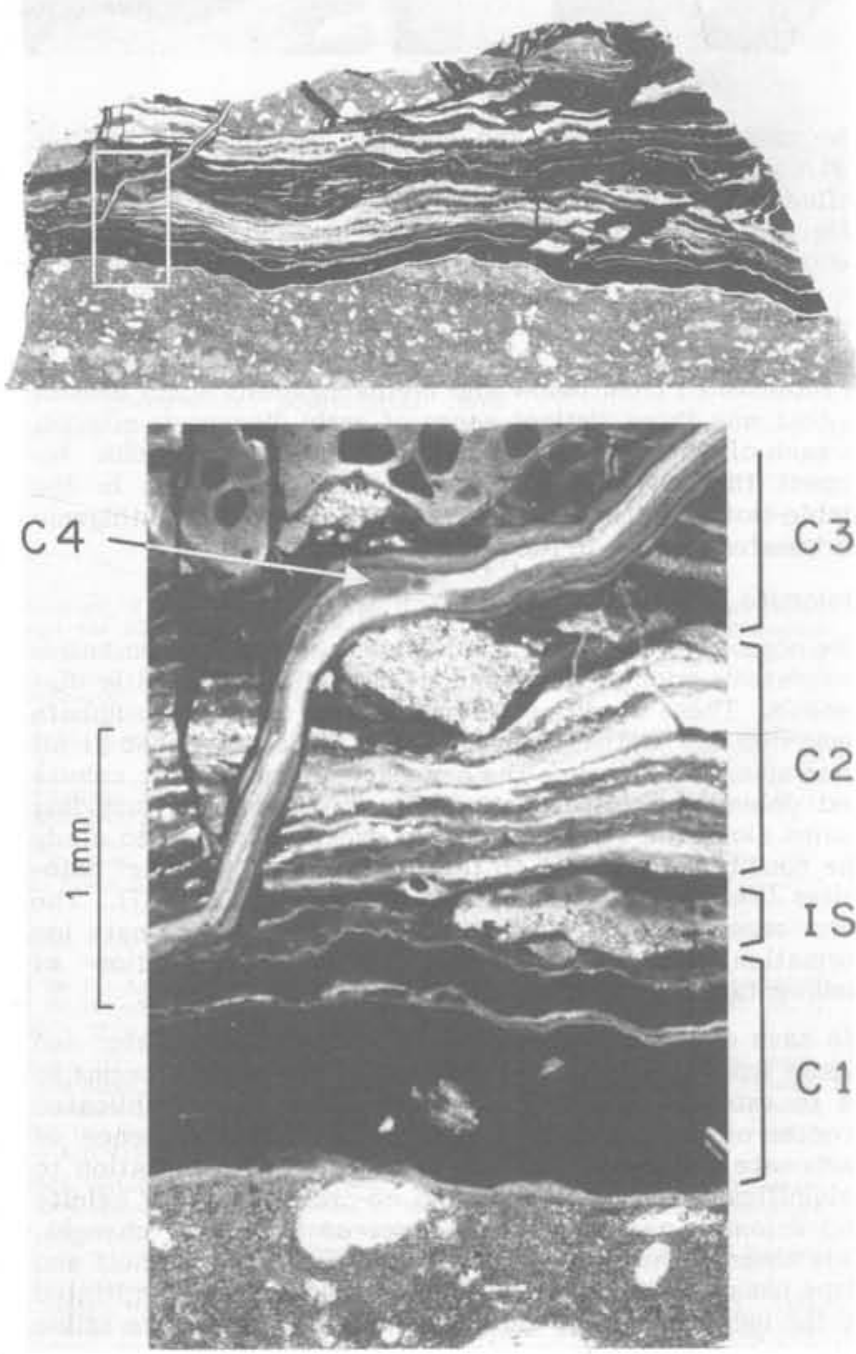

Figure 6: Laminated multi-generation carbonate cements with black opaques. Site 684 (684-13X-CC, $0-3 \mathrm{~cm})$. For explanation see text. 


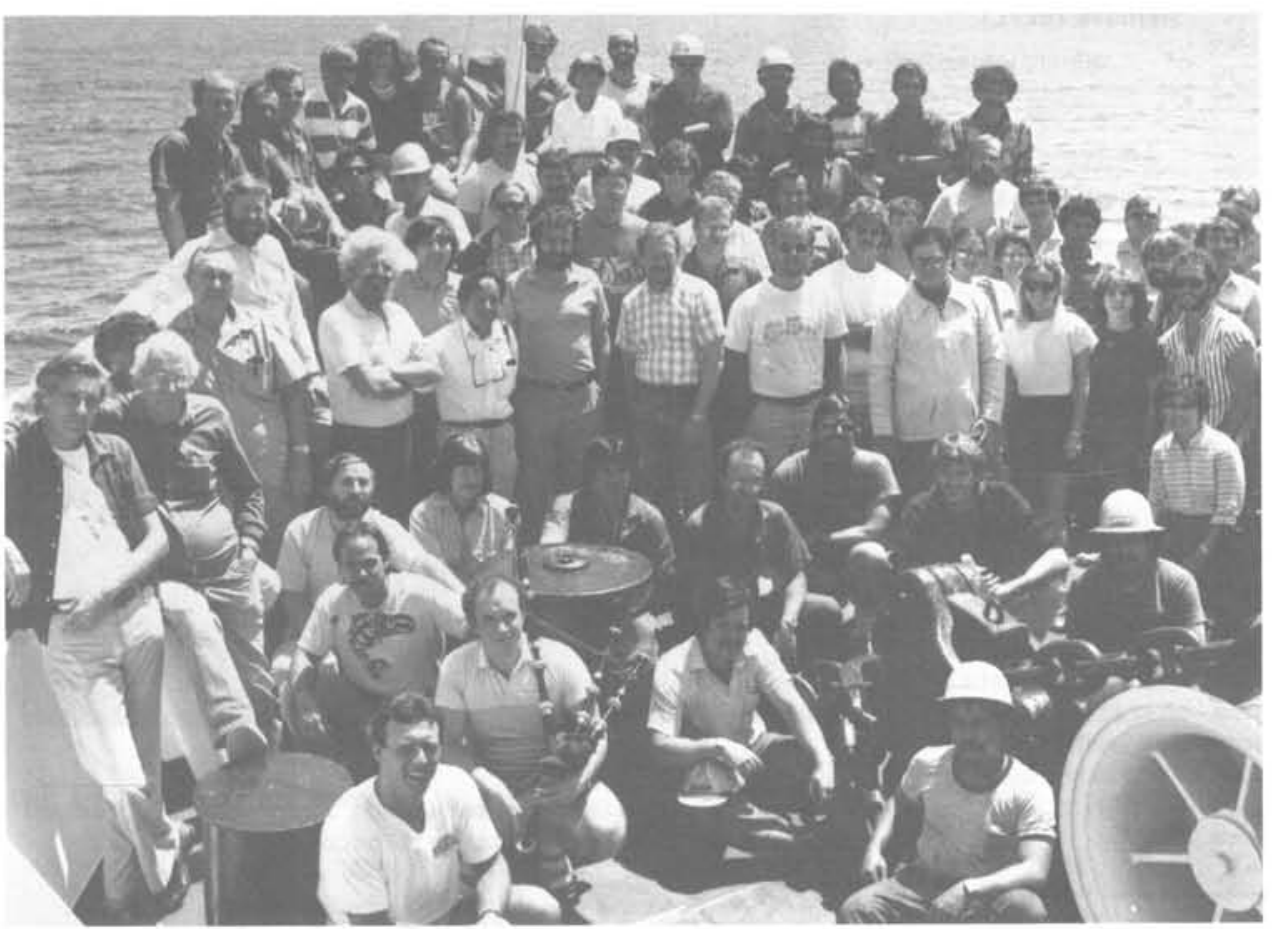

Figure 7: Some of the scientific party and technical staff of Leg 112 aboard JOIDES ResoIution off the coast of Peru, December 1986.

the saline brine. Laminated carbonate cements tainted with disseminated, black opaques here exhibit multigeneration superposition relationships. The matrix is micritic earbonate with cement-filled foraminiferal molds. Cement zones $\mathrm{Cl}$, $\mathrm{C} 2$, and $\mathrm{C} 3$ are separated by surfaces of discontinuity which may indicate periods of corrosion. Zones $\mathrm{Cl}$ and C2 are locally separated by a lens of internal sediment (IS). A fourth generation of fracture-fill cement (C4) cuts all previous growth zonations.

The dissolved sulphate and methane distributions in Hole $681 \mathrm{~A}$ in the Salaverry Basin demonstrate one aspect of the influence that the brine exerts on early diagenetic reactions (Fig. 4). High organic-carbon contents and high rates of sedimentation at this site drive microbial sulphate reduction to completion at a depth' below the sea floor of $27 \mathrm{~m}$, and a zone of methanogenesis develops below (Fig. 5). At greater depth, however, within the zone of brine incursion, sulphate is replenished from below and methanogenesis again ceases. In that way three distinct zones of early diagenesis coexist, in each of which carbonate mineral formation proceeds. We expect that a distinct brine signature is present in the stable-isotope characteristies of the various authigenic carbonates forming in the different zones.

\section{Dolomite Formation}

The organic-rich upwelling facies of the Peru forearc basins generates a wide range of chemical conditions for early diagenesis. These conditions favour intense microbial sulphate reduction and methanogenesis, which were prominent at all sites along the margin. The abundance of authigenic calcite and dolomite confirmed that the differentially subsiding basins along the Peru margin are excellent places to study the conditions that lead to the formation of "organic" dolomites (Kulm, Suess et al., 1984; Suess et al., 1987). The term organic dolomite refers to the mode of carbonate ion formation via microbial and thermal degradation of sedimentary organic matter (Baker and Barnes, 1985).

We have obtained important data on interstitial water and gasses from closely spaced sampling of the various basins so as to establish a reaction sequence for the complicated process of organic dolomite formation. This sequence of carbonate diagenesis proceeds from calcite precipitation to dolomitization of calcite to final co-precipitation of calcite and dolomite as the ratio of dissolved $\mathrm{Mg}$ to $\mathrm{Ca}$ changes. This observed sequence of chemical diagenesis in shelf and slope basins of the Peru continental margin was overprinted by the incursion of the carbonate-bearing sub-surface saline brine described above.

An example of the complex multi-generation superposition relationship of dolomite cements is shown in Figure 6, from a dolomite bed at Site 684 with the highest chlorinities from

\section{Summary and Conclusions}

The Peru convergent margin consists of an upper slope comprised of continental crust and a lower slope comprised of an accretionary complex. The continental erust includes material attached to the continent prior to development of the modern subduction zone, as identified in seismic records by the distinctive cover of slope deposits, essentially of post-Oligocene age. These slope deposits extend to within $15 \mathrm{~km}$ of the trench axis, and at the three sites where they were sampled by drilling they consist of Neogene mudstones above an Oligocene unconformity. The underlying Eocene shelf and upper slope deposits indicate up to $5 \mathrm{~km}$ of subsidence of the continental crust along the front of the margin. Accretion began about 5 Ma ago.

The general landward shift of the coast throughout Neogene time can be seen in the subsidence differences along the two transects. This shift was confirmed by the recovery of a primary coastal upwelling sediment facies of latest Miocene age about $90 \mathrm{~km}$ seaward of the modern zone of upwelling. The vertical tectonic history along the northern transect indicates a general subsidence of the Trujillo Basin with relative stability during the past $10 \mathrm{Ma}$, whereas the Lima Basin area along the southern transect was uplifted, eroded, and subsided rapidly during the same period.

Thus, the ancient centers of coastal upwelling have not been in a stationary geographic position, nor have they shifted in a systematic way, instead they are controlled by the tectonics of each segment of the margin. Superimposed on the vertical tectonic motion were higher frequency oscillations of sea-level and climatic fluctuations. The sedimentary record from upwelling centers located at the edge of the Late Miocene slope in the Lima Basin sector of the margin have probably been removed by erosion. However, redeposited and transported sediments now preserved at the mid-slope area of the Lima Basin may contain a long-term record, as recovered in the slump block with Upper Miocene laminated sediments at $400 \mathrm{~m}$ below the sea floor at Site 688. These laminations contain a primary signal of upwelling comparable to the Quaternary record on the present upper slope, whereas the re-worked matrix contains the long-term history of upwelling. 
Sediments from beneath coastal upwelling eenters are rich in organic matter, and they experience extensive early diagenesis as a result of microbial degradation of this organic substrate. Organic carbon is oxidized by sulphate reduction and methanogenesis in all sections drilled, and the chemical environment thus produced promotes formation of diagenetic minerals, i.e., calcite, dolomite, francolite, chert, and sulphides. This normal sequence of microbial activity and diagenetic mineral formation, mainly of dolomites, is complicated by a hypersaline brine at the shelf. The brine, which originates from some unknown depth in the subsurface, replenished sulphate in the interstitial waters and thereby strongly affected early diagenesis.

Leg 112 Scientific Party (Fig. 7): Co-Chief Scientists: R. von Huene (U.S. Geological Survey, Menlo Park); E. Suess (Oregon State University, Corvallis); Staff Scientist: K.-C. Emeis (Ocean Drilling Program, Texas A\&M University, College Station); Scientists: J. Bourgois (Université $P$ \& $M$ Curie, Paris); J. del C. Cruzado Castaneda (Petroperu, Lima); P. De Wever (Université $P \&$ M Curie, Paris); G. Eglinton (University of Bristol, U.K.); A.W.S. Fernandez (INGEMMET, Lima); R. Garrison (University of California, Santa-Cruz); M. Greenberg (LamontDoherty Geological Observatory, Palisades, N.Y.); P. Hill (Geological Survey of Canada, Bedford, Nova Scotia); M. Ibaraki (Shizouka University, Japan); M. Kastner (Scripps Institution of Oceanography, La Jolla); A.E.S. Kemp (University of Southampton, U.K.); K. Kvenvolden (U.S. Geological Survey); $R$. Landridge (Queen's University, Kingston); $N$. Lindsley-Griffin (University of Nebraska); R. McCabe (Texas A\&M University); J. Marsters (Geological Survey of Canada, Bedford, Nova Scotia); E. Martini (Universität Frankfurt, F.R.G.); L. Ocola (Instituto Geofisico del Peru, Lima); E.H. Paz (Petroperu, Lima); J. Resig (University of Hawaii, Honolulu); $H$. Schrader (Universitet Bergen, Norway); T. Thornburg (Oregon State University, Corvallis); G. Wefer (Universität Bremen, F.R.G.); M. Yamano (Earthquake Research Institute, Tokyo).
Dr. R. von Huene is a marine geologist with the U.S. Geological Survey (Menlo Park, CA 94025, U.S.A.) and has made extensive field studies of convergent tectonics along the Peru-Chile, middle America, western United States, Alaska-Aleutian, and Japanese margins. He was Co-Chief Scientist on four legs of the DSDP and with his co-authors here of Leg 112.

Dr. E. Suess is a marine geochemist (School of Oceanography, Oregon State University, Corvallis, OR 97331, U.S.A.). He works now on Neogene history of eastern boundary current regimes off northern and southern America, characterizing the thermal alteration by back-are volcanism of sediments and fluids along the Antaretic Peninsula, and estimating global subduction-induced fluid and dissolved mass transport and its effect on the geochemical budget.

Dr. K.-C. Emeis is an ODP scientist (Dept. of Oceanography, Texas A\&M University, College Station, TX 77843, U.S.A.). He participated in ODP Legs 107 (Tyrrenean Sea) and Leg 112 and is currently preparing for Leg 117. His research interests include chemical sedimentation, diagenesis of organic-rich sediments, and organic geochemistry.
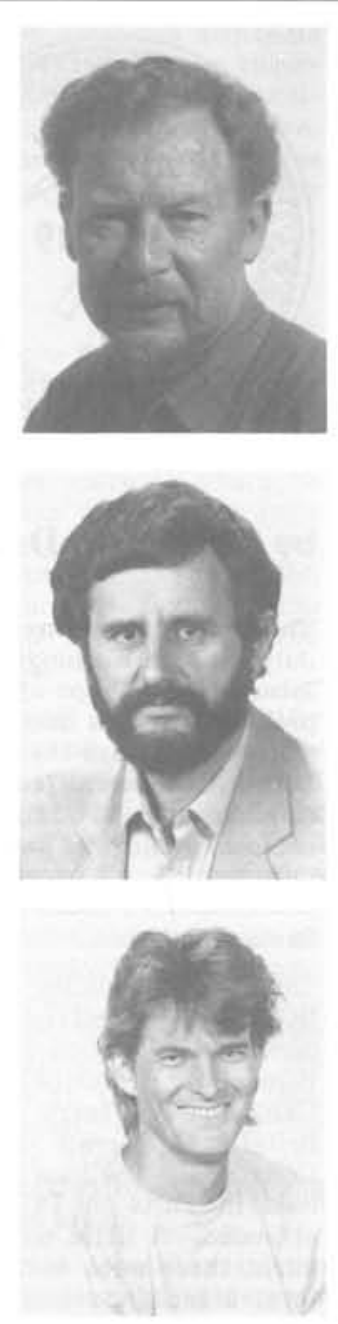

\section{References}

Baker, P.A. and Burns, S.J., 1985. Oecurrence and formation of dolomite in organic-rich eontinental margin sediments. American Association of Petroleum Geology Bulletin, v. 69, no. 11, p. 1917-1930.

Bourgois, J, and others, 1986. Régime tectonique de la marge andine convergente du Pérou. Compte Rendu de T'Academie des Sciences, Paris, v. 303 , Série II, no. 17, p. 1599-1604.

Haq, B.U., Hardenbol, J. and Vail, P.R., 1987. Chronology of fluctuating sea levels since the Triassic. Science, v. 235, no. 4793, p. 1156-1166.

Hussong, D.M. and Taylor, B., 1985. Peru forearc structure and tectonic disruption. EOS, American Geophysical Union Transactions, v. 66, no. 46, p. 1096 (abstract).

Hussong, D.M. and Wipperman, L.K., 1981. Vertical movement and tectonic erosion of the continental wall of the Peru-Chile Trench near $11^{\circ} 30$ 's latitude. Geological Society Ameriea Memoir, v. 154, p. 509-524.

Imbrie, J., Hays, J.D., Martinson, D.G., MeIntyre, A., Mix, A.C., Morley, J.J., Pisias, N.G., Prell, W.L. and Shackleton, N.J., 1984. The orbital theory of Pleistocene climate: Support from a revised chronology of Milankovitch and Climate, Part 1. D. Reidel, p. 269-305.

Kulm, L.D., Schrader, H., Resig, J.B., Thornburg, T.M., Masias, A. and Johnson, L., 1981. Late Cenozoic carbonates on the Peru continental mangin: Lithostratigraphy, biostratigraphy, and tectonic history. Geological Society of America Memoir, v. 154, p. 469-508.
Kulm, L.D., Suess, E. and Thornburg, T.M., 1984. Dolomites in organic-rich muds of the Peru forearc basins: Analogue to the Monterey Formation. In: Garrison, R.E., Kastner, M. and Zenger, D.H. (eds.), Dolomites of the Monterey Formation and Other Organic-Rich Units. Society of Economic Paleontologists and Mineralogists Pacific Section, v. 41, p. 29-47.

Kuim, L.D., Thornburg, T.M. and Dang, S.P., 1984. Drill hole stratigraphy, dredge lithologies, and sample locations. In: Hussong, D.M. and Kulm, L.D. (eds.), Ocean Margin Drilling Program, Regional Atlas Serjes. Marine Science International, Woods Hole, Mass., v, 9, p. 18.

Martinson, G.G., Pisias, N.G., Hays, J.D., Imbrie, J., Moore, Jr., T.C. and Shackleton, N.J., 1987. Age dating and the orbital theory of the lce Ages: Development of a highresolution 0 to 300,000 -year chronostratigraphy. Quaternary Research, v. 27, p.1-29.

Pisias, N.G., Martinson, D.G., Moore, T.C., Jr., Shackleton, N.J., Prell, W., Hays, J. and Boden, G., 1984. High resolution stratigraphic correlation of benthic oxygen isotopic records spanning the last 300,000 years. Marine Geology, v. 56, no. 1-4, p. 119-136.

Reed, T.B., IV and Hussong, D., 1985. Variable vertical tectonies in the Peru fore-are. EOS, American Geophysical Union Transactions, v. 66 , no. 46 , p. 1096 (abstract).

Reimers, C.E. and Suess, E., 1983. Late Quaternary fluctuations in the cycling of orzanic matter of central Peru: A proto-kerogen record. In: Suess, E. and Thiede, J, (eds), Coastal Upwelling: its Sediment Record, v. 10A. Plenum Press, New York, p. 497-526.
Schuette, G. and Schrader, H., 1979. Diatom taphocoenoses in the coastal upwelling area off western South America. Proceedings of the Fifth Symposium on Reeent and Fossil Diatoms. Nova Hedwigia Beihefte, no. 64, p. 359-378.

Suess, E. and Thiede, J., 1983. Responses of the sedimentary regime to present coastal upwelling. In: Suess, E. and Thiede, J. (eds.), Coastal Upwelling: Its Sediment Record, v, 10A. Plenum Press, New York, $604 p$.

Suess, E., Kulm, L.D. and Killingley, J.S., 1987. Coastal upwelling and a history of organic-rich mudstone deposition off Peru. In: Brooks, J. and Fleet, A. (eds.), Marine Petroleum Source Rocks. Geological Society Special Publication, no. 26, p. 181-197.

Thiede, J. and Suess, E., 1983. Sedimentary record of ancient coastal upwelling. Episodes, v. 1983, no. 2, p. 15-18.

Thornburg, T.M., 1985. Multichannel seismic interpretations - Shelf and upper slope basins, In: Hussong, Dretations - Shelf and upper slope basins, In: Hussong, Program, Regional Atlas Series. Marine Science Program, Regional Atlas Series. Marine
International, Woods Hole, Mass, v. 9, p. 8.

Thornburg, T.M. and KuIm, L.D., 1981. Sedimentary basins of the Peru continental margin: Structure stratigraphy, and Cenozoic tectonies from $6^{\circ} \mathrm{S}$ to $16^{\circ} \mathrm{S}$ latitude. Geological Society of America Memoir, v. 154, p. 393-422.

von Huene, R., Kulm, L.D. and Miller, J., 1985. Structure of the frontal part of the Andean Convergent Margin. Journal of Geophysical Research, v. 90 , no. B7, p. 5429-5442, 